\title{
Opportunistic predatory behavior of margay, Leopardus wiedii (Schinz, 1821), in Brazil
}

\author{
Fabiana Rocha-Mendes ${ }^{1,2, *}$ and Gledson V. \\ Bianconi ${ }^{1}$ \\ ${ }^{1}$ Programa de Pós-graduação em Ciências Biológicas \\ - Zoologia, UNESP. CP 199, 13506-900, Rio Claro, \\ São Paulo, Brazil \\ 2 Laboratório de Biologia da Conservação (LaBiC), \\ UNESP. CP 199, 13506-900, Rio Claro, São Paulo, Brazil, \\ e-mail: gabi_frm@terra.com.br \\ ${ }^{*}$ Corresponding author
}

Keywords: bat; chiroptera; feeding behavior; Felidae; predation.

The margay, Leopardus wiedii (Schinz, 1821) ranges from Mexico to Uruguay, occurring in tropical and subtropical forests (Oliveira 1998). Despite its wide distribution, the margay is naturally rare and considered vulnerable in Brazil (Brasil 2003) and in the State of Paraná (Mikich and Bérnils 2004) according to IUCN (2001) criteria, mainly due to deforestation, habitat destruction and fragmentation, and illegal hunting trading.

Although this species has several characteristics that facilitate its identification, such as large and prominent eyes, salient snout, large paws, and long tail (Emmons and Feer 1997), its observation in the field is difficult and rare, as most behavioral information has been obtained in captivity (Oliveira 1994, Azevedo 1996). Evidence suggests that margays seem to be less tolerant of disturbed and modified habitats than other cats, such as Leopardus pardalis (Linnaeus, 1758) and Leopardus tigrinus (Schreber, 1775) (Vaughan 1983, Tello 1986, Emmons and Feer 1997).

Margays are solitary and mainly nocturnal wilds cats. Moreover, they are well adapted to arboreal life, with morphology specifically for climbing trees, such as the $180^{\circ}$ rotation of the feet (Emmons and Feer 1997). They feed mainly on small mammals, birds, and reptiles (Emmons and Feer 1997), but some authors (Konecny 1989, Oliveira 1994) believe that the majority of their diet is composed of arboreal mammals. Here, we report two events of opportunistic predation on bats by margay in remnants of the Brazilian Atlantic Forest.

The first event was observed in a forest fragment $\left(23^{\circ} 52^{\prime} 49.3^{\prime \prime} \mathrm{S}-051^{\circ} 58^{\prime} 21.4^{\prime \prime} \mathrm{W}\right)$ located in the municipality of Fênix, mid-west State of Paraná, southern Brazil. This area (approximately $180 \mathrm{ha}$ ) is bordered by cultivated and pasture lands and exhibits signs of human disturbance, mainly due to illegal wood exploitation in the past (Mikich and Silva 2001). The second event occurred in a forest remnant $\left(23^{\circ} 48^{\prime} 8^{\prime \prime} \mathrm{S}-051^{\circ} 55^{\prime} 39^{\prime \prime} \mathrm{W}\right)$ approximately $10 \mathrm{~km}$ distant from the first event, in the municipality of São Pedro do Ivaí. This area (approximately $550 \mathrm{ha}$ ) is covered by primary disturbed forest bordered by extensive areas of sugar cane plantation, a highway (PR457) and a small river. Both sites are covered by dense canopy (13-14 m, up to 50\% coverage), with several trees reaching up to $20 \mathrm{~m}$ high, a medium strata approximately $8 \mathrm{~m}$ high ( $50 \%$ coverage) and a lower strata mostly of bushes and herbs, ranging from 0.7 to $1.3 \mathrm{~m}$ high (Bianconi et al. 2006). The landscape surrounding the two fragments is a mosaic of small forest remnants (up to $350 \mathrm{ha}$ ) and seriously disrupted riparian forests isolated by cropland. A detailed description of the study area and its plant species can be found in the literature (Mikich and Silva 2001).

Event 1 - During mist-netting bat activities on June 19th and 20th 2003, we found five bats (one Artibeus fimbriatus Gray, 1838, one Artibeus jamaicensis Leach, 1821, two A. lituratus (Olfers, 1818) and one Sturnira lilium (E. Geoffroy, 1810)) dead between 22:35 and 23:55 h. Four were still trapped in the mist-nets, 0.1-1.5 $\mathrm{m}$ above the ground, and one was lying on the ground. Four of the five dead bats exhibited discrete wounds characteristic of the canines of a small cat (Sunquist and Sunquist 2002) on one or more parts of the body. The fifth bat did not present any apparent injuries; however, some damage suggesting strangulation (possibly caused by the pressure applied with the incisors of the cat upon the bat's throat) was observed during autopsy.

The cat species involved was confirmed on the second night (20th), when one adult margay was observed at 19:50 $\mathrm{h}$ sitting near the nets. When it noticed our presence it promptly disappeared into the woods. A second animal, apparently juvenile, based on its significantly smaller size, was observed at 20:35 h. When we arrived to clear the nets it was rearing up on its hind legs, trying to reach a recently mist-netted bat (Artibeus lituratus) $50 \mathrm{~cm}$ above the ground. The cat then walked slowly along the nets for approximately $10 \mathrm{~m}$ before entering the woods. The behavior of the margays observed next to our mist-nets, considered along with the characteristics of the wounding on the dead bats, suggests that one or more individuals were responsible for the death of the bats the previous night.

In the previous night - on March 19th, around 01:45 h, we observed an adult margay followed by two young next to a mist-net. The adult cat was predating an Artibeus Leach, 1821 (n.i.) bat. The bat was on the ground but still trapped to the mist-net. When the adult margay noticed our presence it climbed a nearby tree and dis- 
appeared, but left behind the remains of its prey (part of body and right wing). Both young ran away in the opposite direction. Examining the damage caused to the mistnet by this predation event we concluded that the bat was approximately $1.5 \mathrm{~m}$ above the ground when caught.

Information on the diet of Leopardus wiedii in Brazil was based almost exclusively on fecal (Facure and Giaretta 1996, Wang 2002) and stomach analysis (Ximenez 1982), which revealed the consumption of amphibians, reptiles, birds and their eggs, and mammals. Additionally, Azevedo (1996) observed an individual in the wild feeding on an amphibian and another fighting with an opossum (Didelphis aurita (Wied-Neuwied, 1826)), in southeastern Brazil. Although the consumption of small mammals by L. wiedii was relatively well documented, no previous study in Brazil or abroad (e.g., Mondolfi 1986, Konecny 1989) had ever reported the consumption of bats by this species. Nevertheless, records of other neotropical cats feeding on bats were previously presented by Mondolfi (1986), Emmons (1987), and Bisbal (1986) for Leopardus pardalis, and Emmons (1987) and Stallings (in Iriarte et al. 1990) for Puma concolor (Linnaeus, 1771); all based on feces or stomach contents of animals collected elsewhere. Even though the consumption of mist-netted bats by margays represents an artificial predation scenario, it indicates that margays do recognize bats as potential prey and consequently suggests that bats may be part of their natural diet. However, further studies must be undertaken to evaluate the importance of this food item in the diet of neotropical cats.

\section{Acknowledgements}

We are indebted to the FEMA/IAP/SEMA (Fundo Estadual do Meio Ambiente - FEMA/Instituto Ambiental do Paraná - IAP/ Secretaria de Estado do Meio Ambiente - SEMA) (contract no. 024/02) and the Embrapa Florestas for their financial support, and the owners Fazenda Cagibi and the Usina Vale do Ivaí S/A for their indispensable support, to Urubatan M.S. Suckow for field assistance, to Juliana Quadros and Liliani M. Tiepolo for suggestions on earlier drafts, and Sandra Bos Mikich, Ariovaldo P. Cruz Neto, and Rodrigo P.D. Napoli for editorial assistance and additional suggestions that improved the manuscript, and Sean Tomlinson for assistance with the final English revision.

\section{References}

Azevedo, F.C.C. 1996. Notes on the behavior of the margay Felis wiedii (Schiz, 1821), (Carnivora, Felidae), in the Brazilian Atlantic Forest. Mammalia 60: 325-328.
Bianconi, G.V., S.B. Mikich and W.A. Pedro. 2006. Movements of bats (Mammalia, Chiroptera) in Atlantic forest remnants in southern Brazil. Rev. Bras. Zool. 23: 1199-1206.

Bisbal, F.J. 1986. Food habits of some neotropical carnivores in Venezuela (Mammalia, Carnivora). Mammalia 50: 329-339.

Brasil. 2003. Instituto Brasileiro do Meio ambiente e dos Recursos Naturais Renováveis. Lista da Fauna Brasileira Ameaçada de Extinção. Available online: http://www.ibama.gov.br/ fauna/downloads/lista\%20spp.pdf.

Emmons, L.H. 1987. Comparative feeding ecology of felids in a neotropical rainforest. Behav. Ecol. Sociobiol. 20: 271-283.

Emmons, L.H. and F. Feer. 1997. Neotropical rainforest mammals: a field guide, 2nd edition. The University of Chicago Press, Chicago, IL/London. pp. 307.

Facure, K.G. and A.A. Giaretta. 1996. Food habits of carnivores in a coastal Atlantic forest of southeastern Brazil. Mammalia 60: 499-502.

Iriarte, J.A., W.E. Franklin, W.E. Johnson and K.H. Redfort. 1990. Feeding ecology biogeographic variation of food habitats and body size of the America puma. Oecologia 85: 185-190.

IUCN. 2001. IUCN red list categories and criteria. Version 3.1. IUCN. Species Survival Commission. IUCN, Gland, Switzerland/Cambridge, UK.

Konecny, M.J. 1989. Movement patterns and foods habitats of four sympatric carnivores species in Belize, Central America. In: (K.H. Redford and J.F. Eisenberg, eds) Advances in neotropical mammalogy. The Sandhill Crane Press, Gainsville, FL. pp. 243-464.

Mikich, S.B. and S.M. Silva. 2001. Composição florística e fenologia das espécies zoocóricas de remanescentes de Floresta Estacional Semidecidual no centro-oeste do Paraná, Brasil. Acta Bot. Brasil. 15: 89-113.

Mikich, S.B. and R.S. Bérnils. 2004. Lista da Fauna Ameaçada no Estado do Paraná. Instituto Ambiental do Paraná, Curitiba, Brasil. pp. 764

Mondolfi, E. 1986. Notes on the biology and status of the small wild cats in Venezuela. In: (S.D. Miller and D.D. Everett, eds) Cats of the world: biology, conservation, and management. National Federation, Washington, DC. pp. 125-146.

Oliveira, T.G. 1994. Neotropical cats: ecology and conservation. EDUFMA, São Luiz, Brasil. pp. 220.

Oliveira, T.G. 1998. Leopardus wiedii. Mammalian Species 579: $1-6$.

Sunquist, M. and F. Sunquist. 2002. Wild cats of the world. The University of Chicago Press, Ltd., London. pp. 452.

Tello, J.L. 1986. The situation of the wild cats (Felidae) in Bolivia. CITES Secretariat, Lausanne. pp. 67.

Vaughan, C. 1983. A report on dense forest habitat for endangered wildlife species in Costa Rica. Unpublished report, Universidad Nacional, Heredia.

Wang, E. 2002. Diets of ocelots (Leopardus pardalis), margays (L. wiedii), and oncillas (L. tigrinus) in the Atlantic rainforest in southeast Brazil. Stud. Neotrop. Fauna E. 37: 207-212.

Ximenez, A. 1982. Notas sobre felidos neotropicales VIII. Observationes sobre el contenido estomacal y el comportamiento alimentar de diversas espécies de felinos. Rev. Nordest. Biol. 5: 89-91. 